ОСОБЛИВОСТІ ДЕРЖАВНОЇ ЕКОНОМІЧНОЇ ПОЛІТИКИ ЩОДО ФОРМУВАННЯ ФІНАНСОВО-ГОСПОДАРСЬКОЇ СТАБІЛІЗАЦІї РОБОТИ БІЗНЕСУ ВНАСЛІДОК ЕПІДЕМІОЛОГІЧНИХ ВПЛИВІВ

\title{
PECULIARITIES OF THE STATE ECONOMIC POLICY REGARDING THE FORMATION OF FINANCIAL AND ECONOMIC STABILIZATION OF BUSINESS WORK AS CONSEQUENCE OF EPIDEMIC HYMOLOGY
}

Фінансово-господарська стабілізація на сучасному етапі повинна мати стратегічний характер і бути спрямована на формування і реалізацію цілей господарської діяльності підприємства, а їі результатом має бути економічна стабільність підприємства, стан якої змістовно можна фрормалізувати рівнями фрінансової стійкості, ринкової активності та конкурентоспроможності. Система забезпечення фонансової стабільності має бути спрямована на розвиток підприємства, одночасно формуючи заходи щодо попередження загроз, в тому числі й епідеміологічних впливів.

Найбільш значуще завдання під час організачійних обмежень діяльності для ффункціонування підприємства - че прагнення до раціонального витрачання різного роду ресурсів, в тому числі й фрінансових, що особливо важливо для зміцнення його позицій на ринку. Проведення фрінансового аналізу дозволяє оцінити реалізацію стратегічних завдань підприємстваіскорегувати їхуразі потреби. В результаті аналізу оперативної інсрормації, одержуваної та ссоормованої за підсумком певного виду діяльності, з'ясовуються потреби підприємства для прийняття управлінських рішень щодо покращення фрінансово-господарської стабільності. Система управління бізнесом повинна передбачати діяльність з оцінки ризиків діяльності та пошук варіантів рішень з реагування на них, фрормування та вдосконалення необхідної нормативно-правової бази на основі прийняття управлінських рішень щодо планування подальшої діяльності. Завдяки плануванню стабілізації стає можливим зниження різного роду ризиків на основі перевірки звітних даних, зменшення кількості неесрективних управлінських рішень.

Важливою умовою є висока квалісрікація особливі навички працівників, які оцінюють результати діяльності на основі фрінансово-господарських показників для аналізу відповіднихпроцесів іприйняттяя рішень з корекції на їх основі. Таким чином, планування та стабілізація фрінансово-господарської діяльності дозволяє зберігати вигідне становище бізнесу на ринку, а також виявляти можливі резерви для покращення фрінансового становища і зміцнення його позицій, що $є$ найбільш значущим показником ефективності. В умовах епідеміологічних викликів для отримання конкурентних переваг представники бізнесу постійно змушені йти на ризик, застосовуючи інноваційні технології, впроваджуючи новаторські ідеї, йдучи на сміливі, креативні кроки. Фінансово-господарські втрати пов'язані з неефективним посередництвом, нерегулярним здійсненням платежів та нестабільним фрункціонуванням грошової маси внаслідок епідеміологічних впливів. Втрата доходу бізнесу на чей час, коли умови реалізації фрінансово-господарської діяльності $\epsilon$ невизначеними, виникнення негативних фрінансово-господарських наслідків будуть цілком ймовірними, як $i$ фінансові ризики.
Ключові слова: державна економічна політика, епідеміологічні впливи, формування, управління, фрінансово-господарська стабілізація, бізнес

Financial and economic stabilization at the present stage should be strategic in nature and be aimed at the formation and implementation of economic goals of the enterprise, and its result will be economic stability of the enterprise, the state of which can be formalized by levels of financial stability, market activity and competitiveness. The system of financial stability is aimed at the development of the enterprise, while forming measures to prevent threats, including epidemiological effects.

The most important task during the organizational constraints of the enterprise - is the desire for the most rational use of various resources, including financial, which is especially important to strengthen its position in the market. Conducting financial analysis allows you to assess the implementation of strategic objectives of the enterprise and adjust them if necessary. As a result of the analysis of the operative information received and generated as a result of a certain kind of activity, the needs of the enterprise for acceptance of administrative decisions on improvement of financial and economic stability are filled. The business management system should include activities to assess the risks of activities and search for solutions to respond to them, the formation and improvement of the necessary regulatory framework based on management decisions to plan further activities. Stabilization planning makes it possible to reduce various risks based on the verification of reporting data, reducing the number of ineffective management decisions.

An important condition is the high qualification and special skills of employees who evaluate the results of activities on the basis of financial and economic indicators for the analysis of relevant processes and decision-making on correction based on them. Thus, the planning and stabilization of financial and economic activities allows to maintain a favorable position of business in the market, as well as to identify possible reserves to improve the financial situation and strengthen its position, which is the most important indicator of efficiency.

In the context of epidemiological challenges to gain a competitive advantage, business representatives are constantly forced to take risks, using innovative technologies, implementing innovative ideas, taking bold, creative steps. Financial and economic losses are associated with inefficient mediation, irregular payments and unstable functioning of the money supply due to epidemiological influences. Loss of business income at a time when the conditions for financial and economic activities are uncertain, the probability of negative financial and economic consequences will be quite likely, as well as financial risks.

Key words: state economic policy, epidemiolog ical influences, formation, management, financial and economic stabilization, business. 
Постановка проблеми в загальному вигляді. Глобалізація швидкими темпами розповсюджується в умовах сучасної ринкової економіки, а конкуренція, що підсилюється 3 кожним днем, спонукає суб'єктів господарської діяльності прагнути до збереження стійкого фінансово-господарського становища і пошуку резервів для забезпечення виробничого зростання [8]. Необхідність здійснення фінансової стабілізації зумовлюється підвищенням інвестиційної привабливості бізнесу, поліпшенням структури управління підприємством і досягненням високого рівня фінансово-господарської ефективності. Система організації внутрішнього і зовнішнього контролю, що дозволяє досягти стабільних результатів виробничої діяльності, займає особливе місце в процесі реалізації економічних процесів. Натомість наслідки епідеміологічних загроз для України можуть призвести до того, що пандемічна ситуація вплине на макроекономічні процеси, зруйнувавши зовнішні економічні партнерські відносини та спричинивши відтік капіталу з держави.

Аналіз останніх досліджень і публікацій. На цей час більшість світових експертів говорять про занепад економіки в зв'язку з епідеміологічними загрозами. На їхню думку, фінансово-господарські показники стрімко падають, а негативні впливи поширюються на світову економіку загалом. На фоні фінансово-господарських проблем, що виникли в результаті епідеміологічних впливів, були скасовані багато економічних процесів, зокрема «Брексіт» Великобританії та «торгова війна» США з Китаєм.

Фінансово-господарські впливи привели до закриття кордонів, що призвело до зменшення ринку збуту, неможливості здійснення закупівель за кордоном. Це служить досвідом для державної економічної політики, однак доводиться платити за це занадто велику ціну, оскільки невідомо, як саме ця ситуація в результаті може позначитися на економіці [10]. Однак зрозуміло, що якщо доведеться повторно повноцінно протистояти епідеміологічним впливам і вводити обмеження, то фінансово-господарська система просто не впорається з цим натиском, а більшість підприємств збанкрутують і будуть змушені припинити свою діяльність.

Виділення не вирішених раніше частин загальної проблем. В Україні виявлено низку галузей, які найбільше постраждали від епідеміологічного впливу на фінансово-господарські показники, саме вони найбільш гостро потребують державної підтримки. До цих галузей належать авіаперевезення, готельний бізнес, куль- тура, організація дозвілля та розваг, туризм, фізкультурно-оздоровча діяльність і спорт, громадське харчування, організація виставок, надання побутових послуг населенню.

Для підтримки цих галузей необхідно надавати представникам бізнесу податкові канікули і пільги, а також можливість брати пільгові кредити. Варто видавати підприємствам кредити під 0\% для погашення боргів по заробітній платі співробітникам. Крім цих галузей, великої шкоди завдано малому бізнесу, який надає будь-який вид послуг, оскільки фахівці вважають, що саме він приймає на себе найбільший удар від епідеміологічних загроз [6]. Карантинні обмеження катастрофічно впливають на малий бізнес і галузі сфери обслуговування, через це багатьом підприємствам доводиться призупинити свою роботу або ж зовсім ліквідуватися.

Мета статті полягає в обґрунтуванні державної економічної політики щодо особливостей формування та реалізації фінансовогосподарської стабілізації для роботи бізнесу в період епідеміологічних впливів.

Виклад основного матеріалу. Фінансовогосподарська стабілізація сприяє досягненню цих цілей, тому що допомагає раціонально використовувати матеріальні, трудові та фінансові ресурси. У сучасному світі планування, в тому числі й фінансове, має велике значення у здійсненні господарської діяльності підприємств, підвищенні їх рентабельності. Необхідно провести аналіз фінансового планування, його ролі у діяльності підприємств, а також основні проблеми його реалізації. Фінансово-господарське планування уособлює план всіх доходів та напрямів витрат підприємств, а також встановлення взаємозв'язку між доходами і витратами з метою забезпечення довгострокового розвитку.

У порівнянні з 2019 роком падіння світової економіки у 2020 році склало приблизно 3-5\%, тоді як для України 2020 рік за своїми фінансово-господарськими показниками вважається одним з найгірших. Тому стосовно соціально-економічної підтримки населення необхідно здійснити низку заходів щодо забезпечення товарами першої необхідності, підтримки галузей економіки, які опинилися в зоні ризику, та підтримки малого і середнього бізнесу [2]. У фінансово-господарській стратегії відображається різниця між запланованими витратами і реальними можливостями, що дозволяє зробити коригування з метою досягнення матеріально-фінансової збалансованості.

Фінансово-господарська діяльність складається зі статей, які безпосередньо пов'язані з усіма господарськими показниками 
підприємств, а також з основними розділами його бізнес-плану. Залежно від виду діяльності підприємств, його масштабу і цілей управління можна вибрати необхідний тип фінансового прогнозування, що відображає інтерес у відповідний період, а також необхідні показники. Складання прогнозу прибутку або збитків передбачає спочатку розробку планових показників, а потім їх деталізацію. Наявність даних прогнозу прибутку або збитків дозволяє розрахувати необхідний обсяг ресурсів і витрат на виробництво [4].

Прогноз потоку грошових коштів, що включає їх приплив і відтік, чистий грошовий потік та кінцеве сальдо, визначається тим, що багато витрат, які відображаються під час прогнозування прибутків або збитків, не відображаються на порядку здійснення платежів. Баланс активів і пасивів за формою балансового звіту враховує зміну вартості матеріальних запасів, плановані позики, придбання основних засобів, випуск цінних паперів, а також забезпечення фінансово-господарської стабільності бізнесу і його інвестиційної привабливості, особливо у період епідеміологічних впливів.

Усі елементи фінансово-господарського прогнозування складають єдину систему, вони спрямовані на досягнення спільної мети бізнесу, томупід час зміниплану одного підрозділу виникає необхідність відповідної зміни планів інших. Розроблені плани плавно переходять від одного до іншого, при цьому кожен окремий план потребує корегування в разі будьяких змін у системі. Фінансово-господарське прогнозування має важливе значення в прийнятті управлінських рішень щодо раціонального використання наявних у підприємства коштів [9]. Неграмотне фінансово-господарське планування може привести до дефіциту грошових коштів, низьких показників рентабельності та платоспроможності бізнесу.

Найчастіше прогнозування, складене фахівцями, не відображає цілей і бажань бізнес-структур, відповідно, не підходить безпосередній діяльності підприємства. На багатьох підприємствах існує занадто довга процедура прийняття рішень, узгодження варіантів, а також інформація піддається спотворенню і навіть втрачається в процесі передачі. Ця проблема пов'язана з неефективною організаційною структурою, роз'єднаністю підрозділів і вимагає реорганізації [7]. Фінансовогосподарське прогнозування не може бути уніфікованим, необхідно враховувати його особливості, в тому числі особливості організаційної структури, поточні та стратегічні завдання напряму бізнесу, його регіональну i галузеву специфіку.
Основні проблеми фінансово-господарської діяльності у період епідеміологічних впливів пов'язані з відсутністю ефективної організаційної структури на підприємстві, а саме роз'єднаністю підрозділів, складною системою узгодження рішень, відсутністю необхідної інформації [1]. Також важливою проблемою $€$ відсутність бажання у фахівців цього напряму бізнесу враховувати стратегічні цілі та його регіональні, галузеві та інші особливості. Фінансово-господарське прогнозування у період епідеміологічних загроз відіграє дуже важливу роль у підвищенні рентабельності фінансово-господарської діяльності бізнесу та у забезпеченні раціонального використання наявних у нього фінансових, трудових і матеріальних ресурсів.

Однак на багатьох підприємствах є проблеми у складанні фінансово-господарських прогнозів та їх реалізації, тому ці питання вимагають уваги керівників підприємств, адже тільки вони можуть вплинути на їх оперативне вирішення. Головною метою, яку переслідує система фінансово-господарської стабільності бізнесу, є його успішний розвиток у стратегічній перспективі. Його можна визначити за такими ознаками, як підвищення ринкової вартості й фінансова рівновага [5]. Щоб забезпечити належний рівень фінансово-господарської стабільності бізнесу, необхідно виявити потенційні ризики і загрози, визначити критерії, яким повинна відповідати фінансова стабільність, встановити оптимальну систему моніторингу.

Широке використання таких стабілізаційних сценаріїв, які дозволять бізнесу уникнути банкрутства як результату повного руйнування його фінансово-господарської стабільності за допомогою втрати фінансової самостійності та економічної спроможності. Часто можливість уникнути максимального збитку полягає в якомога більш ранньому їх виявленні, оскільки, виходячи з ідентифікації загроз та наявних шляхів їх виявлення та нейтралізації, можна визначити етапи фінансової стабілізації бізнесу в умовах епідеміологічної кризи [3]. Завданням стабільного функціонування бізнесу в умовах епідеміологічних загроз вважається здатність погашати невідкладні фінансові зобов'язання, щоб не допустити банкрутства. Неплатоспроможність можна досить швидко ліквідувати внаслідок тактичних дій фінансового характеру, однак вона знову виникає, якщо не відновити фінансово-господарську стабільність до її некритичного рівня.

Висновки. Формування фінансово-господарської стабілізації має уособлювати систему заходів, спрямовану як на зниження величини 
поточних фінансових зобов'язань бізнесу, так і на збільшення активів для їх погашення. Це система оперативних захисних дій бізнес-структур, щовключаютьскороченняпоточних потреб, подолання неплатоспроможності, забезпечення фінансової стійкості, досягнення довгострокової рівноваги в оперативному тактично-стратегічному прогнозуванні під час негативних впливів господарського характеру в період епідеміологічних загроз.

Зазначена модель фінансово-господарської стабілізації передбачає досягнення збалансованості активів і короткострокових зобов'язань. У найбільш загальному вигляді модель фінансової рівноваги бізнес-структур можна інтерпретувати як рівність можливого обсягу створення і необхідного обсягу споживання власних фінансово-господарських ресурсів. За умов, якщо суб'єкт господарювання не зберігає темпів приросту обсягу реалізації продукції, для забезпечення фінансової рівноваги в параметри його стратегії повинні бути внесені корективи за допомогою внесення змін до базових фінансово-господарських показників.

\section{ЛIТЕРАТУРА:}

1. Європа і коронавірус. Вдала антикризова стратегія ЄC і що говорять аналітики. URL: https://24tv.ua/ investment/yevropa_i_koronavirus_naskilki_vdala_ antikrizova_strategiya_yes_i_shho_govoryat_analitiki_ n1316553.\%202020.\%2012.04 (дата звернення: 04.04.2021).

2. Заха Д., Мовчан В., Кравчук В., Економічний вплив пандемії Covid-19 на Україну. Аналітичне дослідження. URL: https://rpr.org.ua/wp-content/uploads/
2020/05/GET_UKR_PS_01_2020_ua.pdf (дата звернення: 01.05.2020).

3. Колодяжний М.Г. Вплив карантину на стан злочинності в Україні. Правові засади епідемічної безпеки: виклики та перспективи: матеріали Інтернет конфр. (м. Полтава, 29 квіт. 2020 р.). Харків : Право, 2020. C. 160-153.

4. Комісаренко С.В. Полювання вчених на коронавірус SARS-COV2, що викликає COVID-19: наукові стратегії подолання пандемії. Вісник НАН України. 2020. № 8.

5. Коронавірус може призвести до масштабного економічного шоку в Європі - Лагард. URL: https:// suspilne.media/18912-koronavirus-moze-prizvestido-masstabnogoekonomicnogo-soku-v-evropi-lagard/ (дата звернення: 12.05.2021).

6. Коронавірусна хвороба 2019 в Україні. URL: https://uk.wikipedia.org/wiki (дата звернення: 11.05.2021).

7. Кулицький С. Проблеми розвитку економіки України, обумовлені пандемією коронавірусу COVID-19 у світі, та пошук шляхів їх розв'язання. Україна: події, фракти, коментарі. 2020. № 9. C. 47-53.

8. Малиновська О. Міграція і коронакриза. Міграція. 2020. № 6. С. 12.

9. Мельник К.Ю. Дистанційна робота як засіб забезпечення життєдіяльності людини та держави в умовах обмежувальних заходів, спрямованих на запобігання поширенню коронавірусної інсрекції (COVID-19). Тенденції розвитку науки трудового права та права соціального забезпечення: тези доповідей учасників міжнародної наук.-практ. конфр. (Київ, 16 квітня 2020 р.) / за ред. профр. М.І. Іншина. Київ : ФОП Маслаков, 2020. С. 64-67.

10. Подколзіна С. Як реагують інші країни на COVID-19? URL: https://ces.org.ua/how-countriesreactedon-coroviruscrises/ (дата звернення: 20.08.2021). 